\title{
Glucocorticoid Receptor
}

National Cancer Institute

\section{Source}

National Cancer Institute. Glucocorticoid Receptor. NCI Thesaurus. Code C17071.

Glucocorticoid receptor (777 aa, $\sim 86 \mathrm{kDa}$ ) is encoded by the human NR3C1 gene. This protein plays a role in both chromatin remodeling and transcriptional regulation. 